\title{
Species richness and structure of a breeding passerine bird community in a spruce-dominated boreal forest in central Norway: stability from 1960 s to 2013
}

\section{Olav Hogstad}

Norwegian University of Science and Technology, Section of Natural History, N-7491 Trondheim, Norway; e-mail: Olav.Hogstad@ntnu.no

\begin{abstract}
The density of the breeding passerine bird community in a spruce-dominated forest in central Norway was studied in an area of one $\mathrm{km}^{2}$ during the years 1960 and 1962-1972. In the present study I report on the structure of the passerine community in 2013 and species richness in the periods 1985-1986, 2000-2001 and 2010-2013 in the same forest area, and compare the results with those from the 1960s. The community density during 1960-1972 varied between 142 and 195 territories $/ \mathrm{km}^{2}$, with a mean of 170 . The structure of the community, based on the species' relative densities (the percentage share of each species in the total amount of observations) and the species richness, was basically unchanged. Thirty-seven passerine species were recorded as territorial within the study area, 34 in 1960-1972 and 33 in 2013. Five species held about half (49\%) of the community in 1960-1972: European Robin Erithacus rubecula, Song Thrush Turdus philomelos, Chaffinch Fringilla coelebs, Common Chiffchaff Phylloscopus collybita and Dunnock Prunella modularis, for each of which the mean relative density varied from 6.2 to $11.8 \%$. The same species, except for Dunnock that was replaced by Willow Warbler Phylloscopus trochilus in 2013, made together 53\% of the passerine community. When combining the years 1960-1972 and 2013, Song Thrush and Hooded Crow Corvus cornix had increased in relative densities, Dunnock, Eurasian Blackbird Turdus merula and Willow Tit Poecile montanus had decreased, while European Robin and Chaffinch were the most stable species. Twenty-nine species, i.e. 74\% of the total number of species (39), were recorded in each of the four periods. The remaining species, being absent in one or more periods, accounted each for less than $1 \%$, in total $6 \%$. Despite some numerical changes, the passerine bird community has shown a considerable stability in species richness and structure across the period of 50 years since 1960 .
\end{abstract}

Key words: boreal forest, passerine community, community structure, bird species richness

\section{INTRODUCTION}

Avian diversity of farmland bird species has declined markedly in European agricultural landscapes during the recent decades (Böhning-Gaese \& Bauer 1996, Pain \& Pienowski 1997, BirdLife International 2004, Newton 2004, PECBM 2009). At Lake Constance (SW-Germany, W-Austria, N-Switzerland), a mosaic of forests, arable fields, orchards, fruit plantations and wetlands, it was found that the species richness and number of breeding pairs showed a strong decline from 1980 to 2000 (Bauer et al. 2008). However, the changes in species richness differed markedly between non-passerine birds that remained constant from 1980 to 1990, and even increased between 1990 and 2000, and passerine birds that decreased in both periods. Habitat degradation, human impacts and increasing effects of climate change were suggested as the main drivers of the population changes. On the other hand, in a natural forest in Poland, Tomialojc \& Wesolowski (1996) found that the number of bird species remained basically unchanged from 1970s to 1990s, while the total density increased in coniferous habitats. Furthermore, despite marked changes in vegetation structure, the composition of the breeding bird assemblage did not vary much across forest types (Tomialojc \& Wesolowski 2004). Despite some numerical changes, Wesolowski et al. (2010) found that the breeding bird community and species richness in the same forest were basically unchanged also over the last 35 years.

Although several studies of breeding bird communities of boreal forests in Fennoscandia have been carried out, long-term series of data from the recent decades are rare. Previous studies have shown that changes in bird populations in northern Finland mostly were due to habitat alterations, such as clear-cutting and forest fragmentation (e.g. Järvinen \&Väisänen 1977a, 


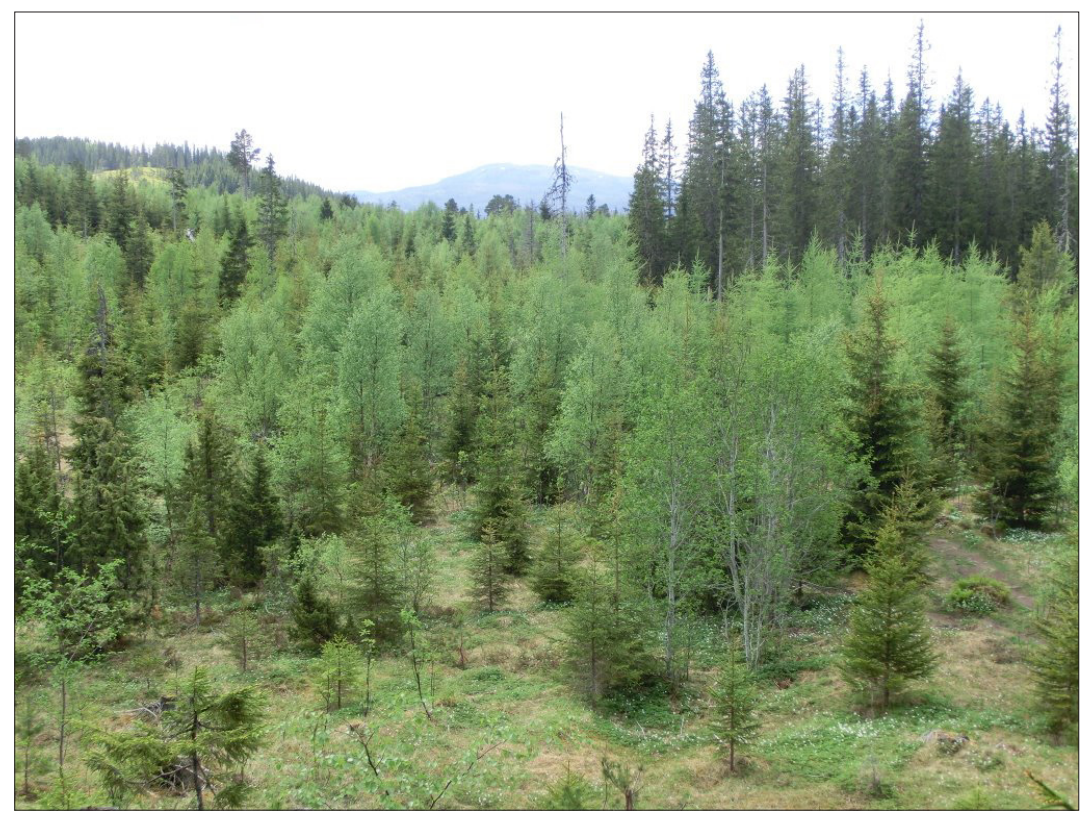

Figure 1. On clear-felled areas, saplings of birches Betula odorata, rowans Sorbus aucuparia and spruce Picea abies appeared. Willow Warbler, Common Chiffchaff and Chaffinch were common in the forest-edge. The deciduous trees, especially rowans, were kept down due to pressure of large herbivores, mainly moose Alces alces.

Väisänen \& Rauhala 1983, Helle 1985). However, Väisänen et al. (1986) who compared bird population trends from 1941 to 1977 , showed that many bird species in North Finnish forests have declined more than the area of old forests had diminished, and Helle \& Järvinen (1986) found a relationship between the long-term population trends and the habitat selection of different bird species. Recently, Virkkala \& Rajasarkka (2011) recorded that birds in boreal areas in Finland showed population density shifts from 1981-1999 to 2000-2009, viz. northern species showed the greatest decrease in south while southern birds increased most in north. In central Norway, Hogstad (2005) found that the breeding passerine bird community in a subalpine heath birch forest remained stable over 30 years (1972-2001). Similar result was found by Enemar et al. (2004) who censused passerine populations from 1963 through 1999 in a subalpine birch forest in Swedish Lapland.

Detailed long-term population studies of passerine birds of boreal coniferous forests in Fennoscandia from the last 40-50 years, however, are lacking. In the years 1960 and 1962-1972, I studied the breeding bird density and species richness of a passerine community in a spruce-dominated boreal forest in central Norway (Hogstad 1993). The main result was that the community showed minor variations across the 12 years. In the present study I report on the relative

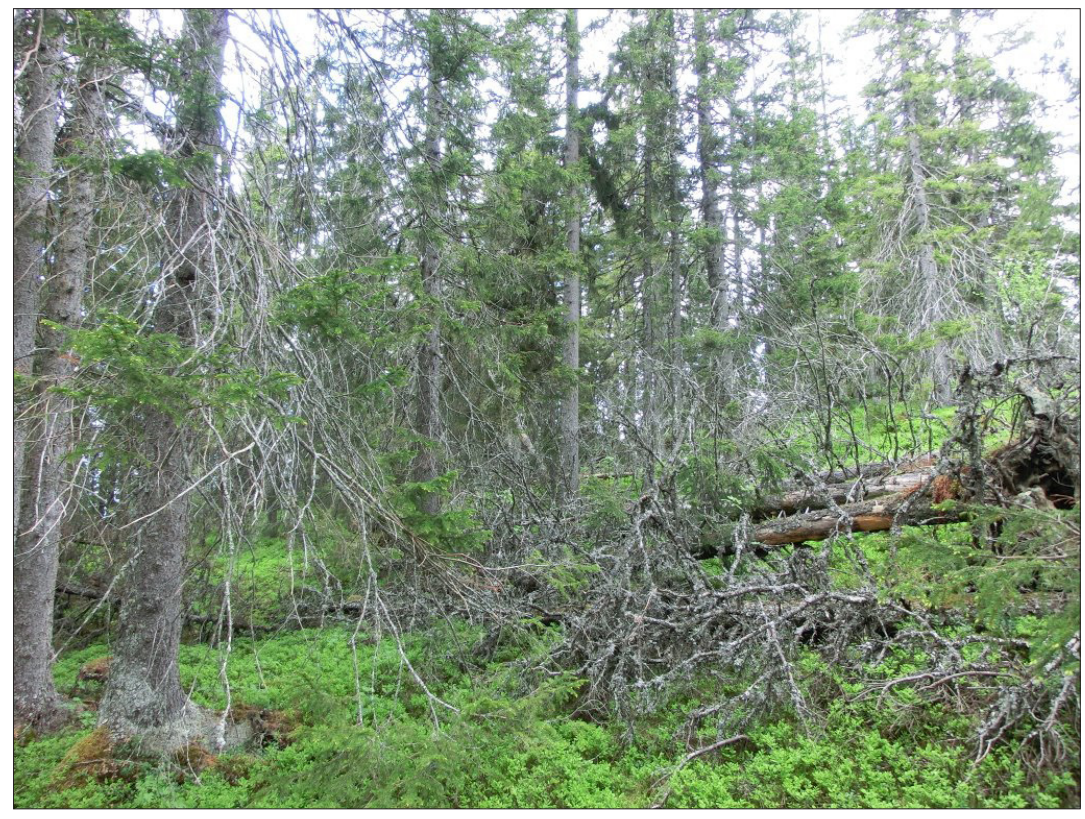

Figure 2. Old mature spruce forest stand. Northern Wren Troglodytes troglodytes, Common Redstart Phoenicurus phoenicurus, Common Treecreeper Certhia familiaris, Crested Tit Lophophanes cristatus, Willow Tit and Spotted Flycatcher Muscicapa striata were common. On wind-exposed places some spruce trees have been broken down by wind, and openings appeared. Such windfall gaps were rapidly colonized by young birches, rowan trees and some spruces. 
densities of the birds in 2013 and the species richness of the passerine community in the same forest area in 1985-1986, 2000-2001 and 2010-2013 and compare the results with those from the 1960s.

\section{MATERIAL AND METHODS}

\section{Study area}

The study was conducted in the Estenstad forest $\left(63^{\circ} 25^{\prime} \mathrm{N}, 10^{\circ} 30^{\prime} \mathrm{E}\right.$; Figure 1 and 2$)$, a part of a lowland coniferous forest area in Trondheim, central Norway. The study plot is about $1 \mathrm{~km}^{2}$, most of it sloping northwestward from 385 to $195 \mathrm{~m}$ in altitude and is bordered by a steep valley to the south, and elsewhere by Sphagnum-bogs and clear-felled areas. The study plot itself consists of about $90 \%$ woodland, $7 \%$ clear-felled area that is more or less overgrown with young spruce trees and deciduous trees, and 3\% bogs. The forest is predominantly Norway spruce Picea abies. Most of the trees are older than 70 years and $15-20 \mathrm{~m}$ in height. The remaining part consists of scattered stands of Scots pine Pinus silvestris, juniper Juniperus communis, and of deciduous trees, mostly birch Betula odorata, grey alder Alnus incana, aspen Populus tremula, rowan Sorbus aucuparia and goat willow Salix caprea. The field layer is dominated by Vaccinum myrtillus, but Trientalis europea, Anemone nemorosa, Pyrola sp., Deschampsia flexuosa and ferns are also common. Thus, the forest is characteristic for the northern boreal vegetation zone in Norway (Moen 1999).

Only small habitat changes have occurred within the study plot during these years. Although small areas were clear-felled in the 1970s, 1990s and 2000s, the forest stands have been relatively unmanaged.

\section{Methods}

The density of the bird community in 1960 and 1962-1972 was estimated by the territory mapping method, in accordance with the international recommendations (Bibby et al. 1992). Each year, 13-20 census visits were made, of which about two thirds took place during the mornings (see Hogstad 1993). Each visit lasted for about 5 to $5 \frac{1}{2} \mathrm{~h}$, and was started alternatively from the eastern and western parts of the area. The census work was carried out from the last week of May to the end of June.

The relative density during the first period (period 1: 1960, 1962-1972) is based on the number of territories estimated by the mapping method. The relative density values given for 2013 is based on line transect work made from the last week of April through June. Walking slowly along unmarked tracks distributed all over within the study area, I recorded all audible and visible observations of small passerines with territorial behaviour (i.e. mostly singing males, but also observations of mated pairs, nest building, feeding of nestlings) within approximately $50 \mathrm{~m}$ in either direction. The species relative density, i.e. the percentage share of each species in the total amount of observations from these line transects is based on 492 observations from 16 visits. Such relative density values have earlier been found to correspond well with that from mapping results (cf. Enemar \& Sjöstrand 1967, Hogstad unpubl.). In 1985-1986, 2000-2001 and 2010-2012 the number of passerine species were recorded by qualitative registrations within the study area during May and June, and were denoted periods 2, 3 and 4, respectively. In period 4, also 2013 were included.

\section{RESULTS}

\section{Community density}

The number of territorial species during the years 1960 and 1962-1972 varied annually between 22 and 33 , and their combined densities (territories $/ \mathrm{km}^{2}$ ), the community density, varied from 142 to 195 territories/ $\mathrm{km}^{2}$, with a mean of 170.1 . Despite a decrease in the community density between 1960 and 1964, an increase was recorded during 1960-1972 (Pearson correlation coefficient $\left.\mathrm{r}_{10}=0.71, \mathrm{p}<0.01\right)$. The mean densities (territories $/ \mathrm{km}^{2}$ ) of the three most abundant species were as follows: Song Thrush Turdus philomelos 20.1, European Robin Erithacus rubecula 19.4, Chaffinch Fringilla coelebs 18.3 .

\section{Community structure}

Thirty-seven passerine species were recorded as territorial within the study area, 34 in 1960-1972 and 33 in 2013 (Table 1). Five species held about half (49\%) of the community in the period 1: Song Thrush, European Robin, Chaffinch, Common Chiffchaff Phylloscopus collybita and Dunnock Prunella modularis, for each of which the mean relative density varied from 6.2 to $11.8 \%$. The same species, except for Dunnock that was replaced by Willow Warbler Phylloscopus trochilus, together formed $53 \%$ of the passerine community in 2013.

In 1960-1972 as well as in 2013, the same three species (Song Thrush, European Robin, Chaffinch) were dominants and comprised each more than $10 \%$ of the community.

The mean relative densities of the 37 species of the community in 1960-1972 and 2013 combined showed that six species accounted for more than 5\% (in total $55 \%$ ), 14 species accounted for 1-5\% (in total 39\%), and 17 species accounted each for less than 1\% (in total $6 \%$; Table 2). All species accounting for more than $1 \%$ were recorded both in the 1960 s and in 2013, whereas 8 of the 17 that were accounted for less than $1 \%$ were recorded in both periods. The distribution of the species of the community, based on their mean relative density 
Table 1. Mean relative densities (number of registrations of a species as per cent of the total registrations of all species observed) of passerines in a coniferous forest in central Norway in May-June in 1960-1972 and 2013. Difference in relative densities is given if $>1 \%$.

\begin{tabular}{|c|c|c|c|}
\hline Species & $\begin{array}{c}1960-1972 \\
\text { Mean \% } \pm \text { SD }\end{array}$ & $\begin{array}{l}2013 \\
\%\end{array}$ & Difference \\
\hline Tree Pipit Anthus trivialis & $3.8 \pm 1.1$ & 2.0 & -1.8 \\
\hline White Wagtail Motacilla alba & $0.3 \pm 0.3$ & 0.4 & \\
\hline Northern Wren Troglodytes troglodytes & $1.9 \pm 0.6$ & 0.8 & -1.1 \\
\hline Dunnock Prunella modularis & $6.2 \pm 0.9$ & 4.1 & -2.1 \\
\hline European Robin Erithacus rubecula & $11.4 \pm 1.3$ & 12.6 & +1.2 \\
\hline Common Redstart Phoenicurus phoenicurus & $1.6 \pm 0.4$ & 1.8 & \\
\hline Whinchat Saxicola rubetra & $0.3 \pm 0.3$ & - & \\
\hline Eurasian Blackbird Turdus merula & $4.7 \pm 1.5$ & 5.9 & +1.2 \\
\hline Fieldfare Turdus pilaris & $2.6 \pm 2.6$ & 2.2 & \\
\hline Song Thrush Turdus philomelos & $11.8 \pm 1.9$ & 13.8 & +2.0 \\
\hline Redwing Turdus iliacus & $5.5 \pm 0.6$ & 7.7 & +2.2 \\
\hline Lesser Whitethroat Sylvia curruca & $0.2 \pm 0.4$ & 0.4 & \\
\hline Garden Warbler Sylvia borin & $0.1 \pm 0.3$ & - & \\
\hline Blackcap Sylvia atricapilla & $0.4 \pm 0.5$ & 0.2 & \\
\hline Icterine Warbler Hippolais icterina & - & 0.4 & \\
\hline Common Chiffchaff Phylloscopus collybita & $9.1 \pm 1.6$ & 5.9 & -3.2 \\
\hline Willow Warbler Phylloscopus trochilus & $3.5 \pm 1.6$ & 3.9 & \\
\hline Goldcrest Regulus regulus & $4.5 \pm 1.7$ & 3.9 & \\
\hline Spotted Flycatcher Muscicapa striata & $0.1 \pm 0.3$ & 0.4 & \\
\hline Pied Flycatcher Ficedula hypoleuca & $0.8 \pm 0.3$ & 1.8 & +1.0 \\
\hline Long-tailed Tit Aegithalos caudatus & $0.1 \pm 0.2$ & - & \\
\hline Crested Tit Lophophanes cristatus & $1.2 \pm 0.2$ & 1.2 & \\
\hline Coal Tit Periparus ater & $1.7 \pm 0.7$ & 1.0 & \\
\hline Willow Tit Poecile montanus & $3.5 \pm 0.6$ & 2.8 & \\
\hline Great Tit Parus major & $0.8 \pm 0.4$ & 2.0 & +1.2 \\
\hline Blue Tit Cyanistes caeruleus & - & 0.8 & \\
\hline Common Treecreeper Certhia familiaris & $0.7 \pm 0.7$ & 1.0 & \\
\hline Eurasian Jay Garrulus glandarius & $0.7 \pm 0.4$ & 0.8 & \\
\hline Common Magpie Pica pica & $0.2 \pm 0.3$ & 0.4 & \\
\hline Hooded Crow Corvus cornix & $1.8 \pm 1.2$ & 2.0 & \\
\hline Common Raven Corvus corax & - & 0.6 & \\
\hline Chaffinch Fringilla coelebs & $10.8 \pm 0.7$ & 11.0 & \\
\hline Brambling Fringilla montifringilla & $3.2 \pm 2.0$ & 1.0 & -2.2 \\
\hline Common Bullfinch Pyrrhula pyrrhula & $2.2 \pm 0.5$ & 2.2 & \\
\hline European Greenfinch Chloris chloris & $0.2 \pm 0.3$ & 1.0 & \\
\hline Eurasian Siskin Spinus spinus & $3.5 \pm 1.0$ & 3.7 & \\
\hline Yellowhammer Emberiza citrinella & $0.6 \pm 0.4$ & - & \\
\hline
\end{tabular}

values (1960-1972 and 2013 combined), is shown in Figure 3.

\section{Changes in community structure}

Two species increased in relative density during 1960-1972 (period 1), viz. Song Thrush $(r=0.59, \mathrm{p}<$ $0.05)$ and Hooded Crow Corvus cornix $(\mathrm{r}=0.72, \mathrm{p}<$ 0.01). Compared to period 1, Song Thrush accounted for further $2 \%$ in 2013, while Hooded Crow remained stable (Table 1). Only one species decreased during 1960-1972, Eurasian Blackbird Turdus merula (r
$=-0.82, \mathrm{p}=0.001)$. When combining the years 1960-1972 and 2013, Song Thrush $(r=0.63, p<0.05)$ and Hooded Crow $(\mathrm{r}=0.66, \mathrm{p}<0.05)$ had increased significantly in relative densities, while Dunnock $(\mathrm{r}=$ $-0.58, \mathrm{p}<0.05)$, Eurasian Blackbird $(\mathrm{r}=-0.61, \mathrm{p}<$ $0.05)$ and Willow Tit Poecile montanus $(\mathrm{r}=-0.56, \mathrm{p}<$ 0.05 ) had decreased.

There was some variation in yearly relative density among the species. Since many species were too few to provide reliable information, I have restricted calculations of variation to the species with a mean 
Table 2. Distribution of 37 passerine species based on their mean relative density values in May-June 1960-1972 and 2013 in a coniferous forest in central Norway.

\begin{tabular}{|c|c|c|}
\hline$>5 \%$ & $1-5 \%$ & $<1 \%$ \\
\hline $\begin{array}{l}\text { Dunnock } \\
\text { European Robin } \\
\text { Song Thrush } \\
\text { Redwing } \\
\text { Common Chiffchaff } \\
\text { Chaffinch }\end{array}$ & $\begin{array}{l}\text { Tree Pipit } \\
\text { Northern Wren } \\
\text { Common Redstart } \\
\text { Eurasian Blackbird } \\
\text { Fieldfare } \\
\text { Willow Warbler } \\
\text { Goldcrest } \\
\text { Crested Tit } \\
\text { Coal Tit } \\
\text { Willow Tit } \\
\text { Hooded Crow } \\
\text { Brambling } \\
\text { Common Bullfinch } \\
\text { Eurasian Siskin }\end{array}$ & $\begin{array}{l}\text { White Wagtail } \\
\text { Whinchat } \\
\text { Lesser Whitethroat }^{\text {Garden Warbler }}{ }^{*} \\
\text { Spotted Flycatcher } \\
\text { Pied Flycatcher } \\
\text { Long-tailed Tit }{ }^{*} \\
\text { Great Tit } \\
\text { Common Treecreeper } \\
\text { Eurasian Jay } \\
\text { Common Magpie } \\
\text { European Greenfinch } \\
\text { Yellowhammer*) } \\
\text { Icterine Warbler } \\
\text { Common Raven } \\
\text { Blue Tit*) }\end{array}$ \\
\hline Total: $\quad 55 \%$ & $39 \%$ & $6 \%$ \\
\hline
\end{tabular}

*) Species observed only in 1969-1972; **) Species observed only in 2013

relative density more than $4 \%$. Among such species that were recorded every year in 1960-1972 and in 2013, Goldcrest Regulus regulus and Eurasian Blackbird varied most and showed a coefficient of variation $(\mathrm{CV}=100 * \mathrm{SD} /$ mean) of 37.0 and 30.4, respectively. Chiffchaff, Dunnock, Song Thrush and Redwing Turdus iliacus had each a CV between 15 and 20, while European Robin and Chaffinch varied least of all species with a CV of 11.3 and 6.6, respectively. Thus, species with a high relative density showed less variation from year to year than species with lower densities $(\mathrm{r}=-0.73, \mathrm{p}<0.05, \mathrm{n}=8$; Figure 4).

To look for interactions among the species' fluctuations during 1960-1972 and 2013, I calculated the correlation coefficients for all pair combinations of the relative densities of the ten most abundant species. No significant positive coefficients were found, while two were negative, viz. European Robin - Goldcrest ( $\mathrm{r}$ $=-0.61, p<0.05)$ and Redwing - Common Chiffchaff $(\mathrm{r}=-0.77, \mathrm{p}<0.01)$.

\section{Species richness}

The number of territorial species, the species richness, varied from 22 in 1964 to 33 in 1971, with a total 34 species for the 12 years. In the next three periods the numbers of species were 32, 34 and 33, respectively (Table 3). The number of species showed an increase during 1960-1972 and $2013(\mathrm{r}=0.60, \mathrm{p}=0.03$; Figure 5). Twenty-nine species, i.e. $74 \%$ of the total number of species (39), were recorded in every period in the Estenstad study plot. The remaining species, being absent in one or more periods, were: Garden Warbler Sylvia borin, Blackcap S. atricapilla and Icterine Warbler Hippolais icterina, species that occur in the area due to higher ambient temperature in May, Common Crossbill Loxia curvirostra that breed in years with good cone crop of spruce, occasional breeding of Long-tailed Tit Aegithalos caudatus, and also Whinchat Saxicola rubetra and Yellowhammer Emberiza citrinella that disappeared when an open area was overgrown with bushes. Blue Tit Cyanistes caeruleus and Hooded Crow were "new" species from the 2000s. After a large influx of Slender-billed Nutcracker Nucifraga caryocatactes macrorhynchos in central Norway in the autumn 1995, the species has bred on several localities in the Trondheim area and several individuals still occurred in 2013. Thus, except for a few species, the Estenstad forest has been inhabited by the same set of species over a period of 50 years.

\section{DISCUSSION}

The stability of the passerine community, as demonstrated in the Estenstad forest, corresponds with that from coniferous forest areas elsewhere in Europe during 1995-2008 (PECBMS 2009). Twenty-nine of the 32-34 species recorded in Estenstad were found in every of the four periods studied. Five of these species held about $50 \%$ of the total community, while most species were represented by low relative densities. The combination of high species richness with low 


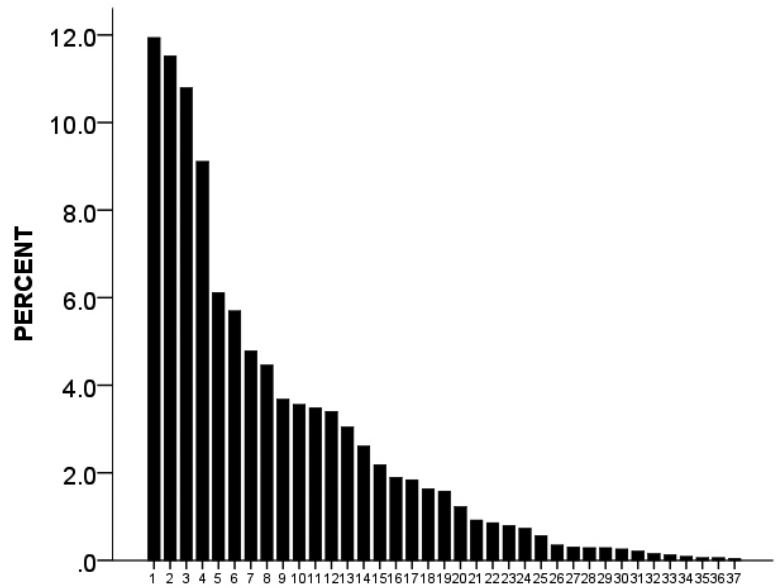

Figure 3. Distribution of mean relative density values of 37 passerine species recorded in a coniferous forest in central Norway in May-June in 1960-1972 and 2013. The six most abundant species, each comprising more than $5 \%$, are: 1 = Song Thrush, 2 = European Robin, 3 = Chaffinch, $4=$ Common Chiffchaff, 5 = Dunnock, $6=$ Redwing.

densities of the majority of the species is probably a feature of central and northern coniferous forests in the Palearctic (cf. Haila \& Järvinen 1990, Tomialojc \& Wesolowski 2004). Thus, also in the strictly protected Bialowieza National Park in Poland, Wesolowski et al. (2010) recorded 34-36 species per season in the coniferous forest part, the majority with low densities. Since the number of species is relatively constant over time, it may be suggested that the species number can be predicted from habitat measures, and that similar habitats in different regions contain similar numbers

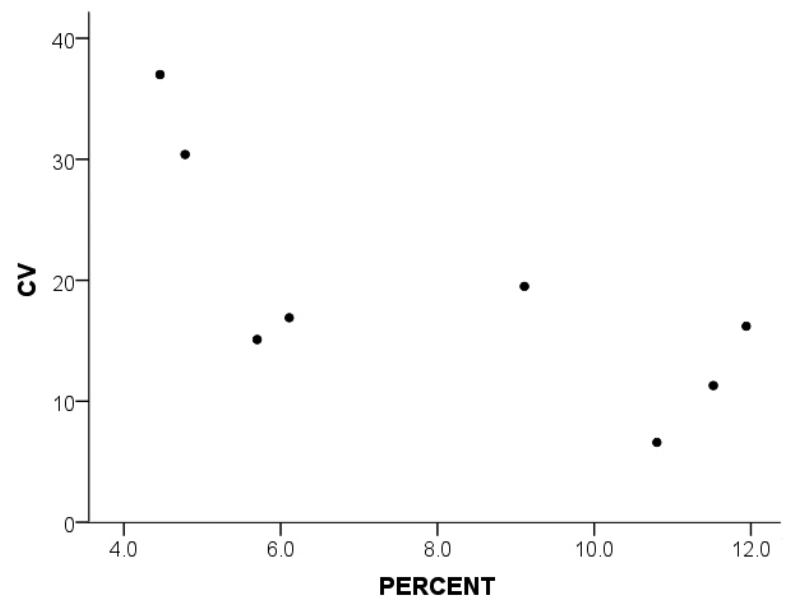

Figure 4. The relationship between relative density (\%) and coefficient of variation ( $\mathrm{CV}=100 * \mathrm{SD} /$ mean $)$ of eight passerine species recorded in a coniferous forest in central Norway in May-June 1960-1972 and 2013 (Pearson correlation: $\mathrm{r}=-0.73, \mathrm{p}=0.03$ ). of species (cf. Wiens 1989). Even if the total density of passerine communities may vary, the shape of the species-density distributions in coniferous forests may be fairly alike, independent of climatic zone (Tomialojc \& Wesolowski 2004).

Despite some changes in relative densities of a few species, the bird assemblage in the spruce-dominated forest in Estenstad remained fairly stable over the 50 year period. As found in the present study, changes in the habitat structure as treefall gaps or small clearfelled areas in the Bialowieza forest, did not result in any addition of new species (Fuller 2000). Local effects of relatively small habitat alterations such as forest thinning or clear-felling apparently has minor consequences on the species density, probably because most passerine species of boreal forests are habitat generalists (cf. Virkkala 1991, Virkkala \& Rajasarkka 2011). Habitat changes within the area may render it unsuitable for some species, whereas other species may take advantage of it. Thus, an increase in the "deciduous forest species" of Sylvia and Phylloscopus should be expected as a result of growth of deciduous saplings after clear-felling, but, as also found by Matsuoka et al. (2012), few measurable data on bird densities were found due to local changes in the habitat. However, factors operating on the local scale may affect some populations, e.g. the cone crop for Common Crossbill and Eurasian Siskin Spinus spinus, loss of open areas for Whinchat and Yellowhammer, and higher ambient temperature in May for Sylvia species.

As expected, species with low relative densities varied more from year to year than more numerous species in the Estenstad forest. The same pattern has been found elsewhere (cf. Järvinen \& Väisänen 1977a,b, Williamson 1981, James \& Wamer 1982). The large yearly variation found in the numerous Goldcrest, however, is probably due to its small body size and high metabolic rate which may result in high mortality in winter. Thus, there was a significant relationship between reduction in population size and temperature between November and March, varying from 76 to $96 \%$, in a spruce-dominated forest near Oslo from 1966 to 1972 (Hogstad 1984). However, recoveries are equally rapid after two or more successive "normal" winters.

Evidence for competition within the community was practically non-existent. Although European RobinGoldcrest and Redwing-Common Chiffchaff fluctuated in opposite directions, these species are so different that they are unlikely to have been in competition. Thus, competitive relationships were not so prevalent as to influence the fluctuations of the individual species. Holmes et al. (1986) found during the years 19691984 that most species fluctuated independently of one another, suggesting that their variations were influenced by different combinations of factors. Similar findings are documented from studies of other woodland bird 
Table 3. Passerine bird species recorded within an area of one $\mathrm{km}^{2}$ in a coniferous forest in central Norway in May-June during four periods; 1960-1972, 1985-1986, 2000-2001 and 2010-2013.

\begin{tabular}{|c|c|c|c|c|}
\hline Species & 1960-1972 & 1985-1986 & $2000-2001$ & 2010-2013 \\
\hline Tree Pipit & $\mathrm{x}$ & $\mathrm{x}$ & $\mathrm{x}$ & $\mathrm{x}$ \\
\hline White Wagtail & $\mathrm{x}$ & $\mathrm{x}$ & $\mathrm{x}$ & $\mathrm{x}$ \\
\hline Northern Wren & $\mathrm{x}$ & $\mathrm{x}$ & $\mathrm{x}$ & $\mathrm{x}$ \\
\hline Dunnock & $\mathrm{x}$ & $\mathrm{x}$ & $\mathrm{x}$ & $\mathrm{x}$ \\
\hline European Robin & $\mathrm{x}$ & $\mathrm{x}$ & $\mathrm{x}$ & $\mathrm{x}$ \\
\hline Common Redstart & $\mathrm{x}$ & $\mathrm{x}$ & $\mathrm{x}$ & $\mathrm{x}$ \\
\hline Whinchat & $\mathrm{x}$ & - & - & - \\
\hline Eurasian Blackbird & $\mathrm{x}$ & $\mathrm{x}$ & $\mathrm{x}$ & $\mathrm{x}$ \\
\hline Fieldfare & $\mathrm{x}$ & $\mathrm{x}$ & $\mathrm{x}$ & $\mathrm{x}$ \\
\hline Song Thrush & $\mathrm{x}$ & $\mathrm{x}$ & $\mathrm{x}$ & $\mathrm{x}$ \\
\hline Redwing & $\mathrm{x}$ & $\mathrm{x}$ & $\mathrm{x}$ & $\mathrm{x}$ \\
\hline Lesser Whitethroat & $\mathrm{x}$ & $\mathrm{x}$ & $\mathrm{x}$ & $\mathrm{x}$ \\
\hline Garden Warbler & $\mathrm{x}$ & - & $\mathrm{x}$ & - \\
\hline Blackcap & $\mathrm{x}$ & $\mathrm{x}$ & - & $\mathrm{x}$ \\
\hline Icterine warbler & - & - & - & $\mathrm{x}$ \\
\hline Common Chiffchaff & $\mathrm{x}$ & $\mathrm{x}$ & $\mathrm{x}$ & $\mathrm{x}$ \\
\hline Willow Warbler & $\mathrm{x}$ & $\mathrm{x}$ & $\mathrm{x}$ & $\mathrm{x}$ \\
\hline Goldcrest & $\mathrm{x}$ & $\mathrm{x}$ & $\mathrm{x}$ & $\mathrm{x}$ \\
\hline Spotted Flycatcher & $\mathrm{x}$ & $\mathrm{x}$ & $\mathrm{x}$ & $\mathrm{x}$ \\
\hline Pied Flycatcher & $\mathrm{x}$ & $\mathrm{x}$ & $\mathrm{x}$ & $\mathrm{x}$ \\
\hline Long-tailed Tit & $\mathrm{x}$ & - & - & - \\
\hline Crested Tit & $\mathrm{x}$ & $\mathrm{x}$ & $\mathrm{x}$ & $\mathrm{x}$ \\
\hline Coal Tit & $\mathrm{x}$ & $\mathrm{x}$ & $\mathrm{x}$ & $\mathrm{x}$ \\
\hline Willow Tit & $\mathrm{x}$ & $\mathrm{x}$ & $\mathrm{x}$ & $\mathrm{x}$ \\
\hline Great Tit & $\mathrm{x}$ & $\mathrm{x}$ & $\mathrm{x}$ & $\mathrm{x}$ \\
\hline Blue Tit & - & - & $\mathrm{x}$ & $\mathrm{x}$ \\
\hline Common Treecreeper & $\mathrm{x}$ & $\mathrm{x}$ & $\mathrm{x}$ & $\mathrm{x}$ \\
\hline Eurasian Jay & $\mathrm{x}$ & $\mathrm{x}$ & $\mathrm{x}$ & $\mathrm{x}$ \\
\hline Common Magpie & $\mathrm{x}$ & $\mathrm{x}$ & $\mathrm{x}$ & $\mathrm{x}$ \\
\hline Slender-billed Nutcracker & - & $\mathrm{x}$ & $\mathrm{x}$ & - \\
\hline Hooded Crow & $\mathrm{x}$ & $\mathrm{x}$ & $\mathrm{x}$ & $\mathrm{x}$ \\
\hline Common Raven & - & - & $\mathrm{x}$ & $\mathrm{x}$ \\
\hline Chaffinch & $\mathrm{x}$ & $\mathrm{x}$ & $\mathrm{x}$ & $\mathrm{x}$ \\
\hline Brambling & $\mathrm{x}$ & $\mathrm{x}$ & $\mathrm{x}$ & $\mathrm{x}$ \\
\hline Common Bullfinch & $\mathrm{x}$ & $\mathrm{x}$ & $\mathrm{x}$ & $\mathrm{x}$ \\
\hline European Greenfinch & $\mathrm{x}$ & $\mathrm{x}$ & $\mathrm{x}$ & $\mathrm{x}$ \\
\hline Eurasian Siskin & $\mathrm{x}$ & $\mathrm{x}$ & $\mathrm{x}$ & $\mathrm{x}$ \\
\hline Common Crossbill & - & $\mathrm{x}$ & $\mathrm{x}$ & - \\
\hline Yellowhammer & $\mathrm{x}$ & $\mathrm{x}$ & - & - \\
\hline Number of species: & 34 & 32 & 34 & 33 \\
\hline
\end{tabular}

communities (Virkkala 1991, Hogstad 1993, Morozov 1993, Enemar et al. 2004).

Although patterns of the small changes observed in some species in Estenstad may be accounted for by local changes in the habitat, it has been demonstrated elsewhere that a number of migrants can be influenced by factors operating on their wintering grounds and along migration routes (Newton 2004, Goodenough et al. 2009). Thus, Blue Tit and Hooded Crow, new in Estenstad after 2000, are among the species that have increased in Europe from 1991 to 2006. Likewise, the positive trend in the relative density of Song Thrush 


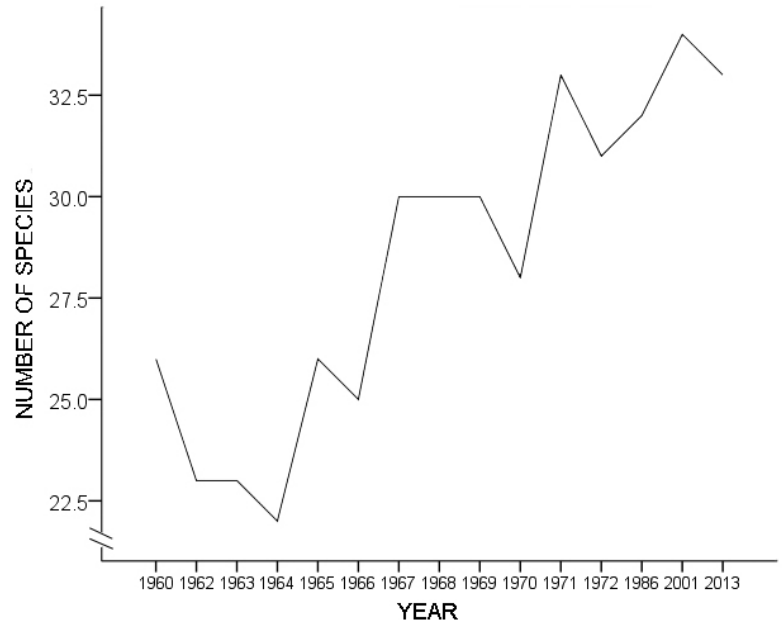

Figure 5. Annual number of species of a passerine bird community recorded in a coniferous forest in central Norway in May-June 1960-1972, 1986 (1985-1986), 2001 (2000-2001) and 2013 (2010-2013) (Pearson correlation: r $=0.60, \mathrm{p}=0.03$ ).

in Estenstad forest was similar to the regional trends observed on national scales in Norway (Husby \& Stueflotten 2009) and Sweden (Lindström et al. 2009) during 1995-2008. Also the decrease in relative density of Dunnock in Estenstad corresponds with that found elsewhere in Europe (PECBMS 2009).

To conclude: except for some numerical changes, the breeding passerine bird community in the sprucedominated coniferous forest in central Norway has been inhabited by the same set of species and shown a considerable stability in species richness and structure across the period of 50 years since 1960. As some of the few population changes recorded in the coniferous forest apparently are in accordance with long-term population trends in northern Europe, it may be suggested that these changes are induced by factors outside the forest area.

\section{REFERENCES}

Bauer, H.-G., Lemoine, N. \& Peintinger, M. 2008. Avian species richness and abundance at Lake Constance: diverging long-term trends in passerines and nonpasserines. Journal of Ornithology 149: 217-222.

Bibby, C.J., Burgess, N.D. \& Hill, D.A. 1992. Bird Census Techniques. Academic Press, London.

BirdLife International 2004. Birds in Europe: population estimates, trends and conservation status. BirdLife International, Cambridge.

Böhning-Gaese, K. \& Bauer, H.-K. 1996. Change in species abundance, distribution, and diversity in a central European bird community. Conservation Biology 10: 175-187.

Enemar, A. \& Sjöstrand, B. 1967. The strip survey as a complement to study area investigations in bird census work. Vår Fågelvärld 26: 111-130.

Enemar, A., Sjøstrand, B., Andersson, G. \& Proschwitz, T. 2004. The 37-year dynamics of a subalpine passerine bird community, with special emphasis on the influence of environmental temperature and Epirrita autumnata cycles. Ornis Svecica 14: 63-106.

Fuller, R.J. 2000. Influence of treefall gaps on distributions of breeding birds within interior old-growth stands in Bialowieza forest, Poland. Condor 102: 267-274.

Goodenough, A.E., Elliot, S.L. \& Hart, A.G. 2009. The challenges of conservation for declining migrants: are reserve-based initiatives during the breeding season appropriate for the Pied Flycatcher Ficedula hypoleuca? Ibis 151: 429-439.

Haila, Y. \& Järvinen, O. 1990. Northern conifer forests and their bird species assemblages. Pp. 61-85 in Keast, A. (ed.). Biogeography and ecology of forest bird communities. SPB Academic Publishing, Hague.

Helle, P. 1985. Effects of forest fragmentation on bird densities in northern boreal forests. Ornis Fennica 62: $35-41$.

Helle, P. \& Järvinen, O. 1986. Population trends of North Finnish land birds in relation to their habitat selection and changes in forest structure. Oikos 46: 107-115.

Hogstad, O. 1984. Variation in numbers, territoriality and flock size of a Goldcrest Regulus regulus population in winter. Ibis 126: 296-306.

Hogstad, O. 1993. Structure and dynamics of a passerine bird community in a spruce-dominated boreal forest. Annales Zoologici Fennici 30: 43-54.

Hogstad, O. 2005. Numerical and functional responses of breeding passerine to mass occurrence of geometrid caterpillars in a subalpine birch forest: a 30-year study. Ibis 147: 77-91.

Holmes, R.T., Sherry, T.W. \& Sturges, F.W. 1986. Bird community dynamics in a temperate deciduous forest: long-term trends at Hubbard Brook. Ecological Monographs 56: 201-220.

Husby, M. \& Stueflotten, S. 2009. Norsk Hekkefugltaksering - Bestandsutvikling i HFT-områdene for 57 arter 1995-2008. Norsk Ornitologisk Forening, NOF rapport 6, 2009. (In Norwegian)

James, F.C. \& Wamer, N.O. 1982. Relationships between temperate forest bird communities and vegetation structure. Ecology 63: 159-171.

Järvinen, O. \& Väisänen, R.A. 1977a. Recent quantitative changes in the populations of Finnish land birds. Polish Ecological Studies 3: 177-188.

Järvinen, O. \& Väisänen, R.A. 1977b. Long-term changes of the North European land bird fauna. Oikos 29: 225-228.

Lindström, Å., Green, M., Ottwall, R. \& Svensson, S. 2009. Övervakning av fåglarnas populationsutveckling. Årsrapport för 2008. Ekologiska institutionen, Lunds universitet. (In Swedish)

Matsuoka, S.M., Johnson, J.A. \& Dellasala, D.A. 2012. Succession of bird communities in young temperate 
rainforests following thinning. Journal of Wildlife Management 76: 919-931.

Moen, A, 1999. National Atlas of Norway: Vegetation. Norwegian Mapping Authority, Hønefoss.

Morozov, N.S. 1993. Short-term fluctuations in a South-Taiga bird assemblage - support for an individualistic view. Ornis Fennica 70: 177-188.

Newton, I. 2004. The recent declines of farmland bird populations in Britain: an appraisal of causal factors and conservation actions. Ibis 146: 579-600.

Pain, D.J. \& Pienowski, M.W. 1997. Farming and birds in Europe: The common agricultural policy and its implications for bird conservation. Academic Press, London.

PECBMS 2009. State of Europe's common birds, 2005. CSO/ RSPB, Prague.

Tomialojc, L. \& Wesolowski, T. 1996. Structure of a primaeval forest bird community during 1970s and 1990s (Bialowieza National Park, Poland). Acta Ornithologica 31: 133-154.

Tomialojc, L. \& Wesolowski, T. 2004. Diversity of the Bialowieza Forest avifauna in space and time. Journal of Ornithology 145: 81-92.

Väisänen, R.A. \& Rauhala, P. 1983. Succession of land bird communities on large areas of peatland drained for forestry. Annales Zoologici Fennici 20: 115-127.

Väisänen, R.A., Järvinen, O. \& Rauhala, P. 1986. How are extensive, human-caused habitat alterations expressed on the scale of local bird populations in boreal forests? Ornis Scandinavica 17: 282-292.

Virkkala, R. 1991. Annual variation of northern Finnish forest and fen bird assemblages in relation to spatial scale. Ornis Fennica 68: 193-203.

Virkkala, R. \& Rajasarkka, A. 2011. Northward density shift of bird species in boreal protected areas due to climate change. Boreal Environment Research 16: 2-13.

Wesolowski, T., Mitrus, C., Czeszczewik, D. \& Rowinski, P. 2010. Breeding bird dynamics in a primeval temperate forest over thirty-five years: variation and stability in the changing world. Acta Ornithologica 45: 209-232.

Wiens, J.A. 1989. The ecology of bird communities. Vol 2. Processes and variations. Cambridge University Press, Cambridge.

Williamson, M. 1981. Island populations. Oxford University Press, Oxford.

Received 14 August 2013. Accepted 17 October 2013 